\title{
SIASAT . \\ PERUBAHAN MUSIMAN (SEASONALITY) PASAR MODAL DAN EFEK KONTAGION DI NEGARA-NEGARA ASEAN
}

\author{
Dwipraptono Agus Harjito \\ Universitas Islam Indonesia Yogyakarta \\ e-mail: agus_h@fe.uii.ac.id
}

\begin{abstract}
This study was to investigate the contagion effect of seasonality in stock markets in the ASEAN region. The study employed the month-end closing prices of each country's based stock market indexes over the period of January 1990 to December 2007. Using Granger causality test, the study found evidence of causal linkages in the markets with Singapore as the leader in majority of the cases. The study also investigated for causal linkages due specifically to seasonality effect. The results deviated from those of the general market performance with respect to the leader-follower linkages but its lended strong support to the view that seasonality effect in some stock markets are contagious.
\end{abstract}

Keywords:seasonality effect; contagion effect; ASEAN countries

\section{PENDAHULUAN}

Pada pertengahan tahun 1997 perekonomian negara-negara ASEAN mengalami krisis ekonomi. Dimulai dari negara Thailand yang mengalami kesulitan akibat semakin membesarnya defisit transaksi berjalan negara tersebut selama lebih kurang 5 tahun terakhir. Keadaan ini diperberat oleh memburuknya kinerja perbankan Thailand yang diakibatkan oleh besarnya kredit macet yang belun teratasi. Kondisi ini menimbulkan krisis ekonomi yang ditandai dengan jatuhnya nilai tukar mata uang Baht terhadap dolar Amerika, besarnya arus modal keluar negeri (capital outflows), dan menipisnya cadangan devisa untuk pembangunan.

Perekonomian diantara negara-negara dunia termasuk antar negara-negara ASEAN sudah terintegrasi. Hal ini ditunjukkan dengan saling berpengaruhnya keadaan ekonomi di suatu negara terhadap negara lainnya. Oleh karena itu, dalam waktu yang singkat, krisis ekonomi yang terjadi di Negara Thailand tersebut di atas sudah menjalar ke negara-negara ASEAN lainnya ter- utama Philipina, Malaysia, dan Indonesia. Efek menjalarnya pengaruh krisis ekonomi ini sering dinamakan sebagai efek kontagion. Efek ini ternyata memiliki dampak yang berbeda bagi negara-negara industri baru (Newly Industrial Countries, NICs) seperti Korea, Hongkong, Taiwan dan Singapura. Ketika it, Negara Korea merupakan negara yang paling parah terkena dampak krisis ini. Sedangkan negara lainnya, seperti Hongkong, Taiwan, dan Singapore, meskipun mengalami krisis tetapi jangka waktunya tidak berkepanjangan.

Efek penularan (contagion effect) dapat terjadi bagi semua kejadian di berbagai bidang baik krisis ekonomi maupun keuangan. Krisis di bidang keuangan seperti fluktuasi harga saham yang terjadi di suatu pasar modal berdampak pada fluktuasi menurunnya return saham dan pada akhirnya berpengaruh pada pola abnormal return sebagai tolok ukur kinerja saham yang bersangkutan. Secara khusus, pola abnormal return saham merupakan isu yang agak baru dalam literatur anomali pasar modal. Namun demikian, perubahan 
musiman harga saham di pasar modal, khususnya kesan anomali efek Januari sebagai efek musiman telah lama menjadi isu yang menarik dalam penelitian empiris bidang keuangan. Lebih spesifik lagi bahwa efek Januari secara khusus telah diteliti berkait dengan hipotesis pasar efisien sejak masalah tersebut diperkenalkan tahun 1976. Hal ini memang benar berlaku terutama di pasar modal negara maju seperti pasar modal New York (New York Stock Exchange). Penelitian yang mendukung berlakunya anomali efek Januari telah dilakukan pula oleh Rozeff and Kinney (1976), dan Haugen and Jorion (1996).

Sekalipun penelitian-penelitian di pasar modal yang lain tidak menemukan hasil yang meyakinkan, Gultekin and Gultekin (1983) masih menemukan adanya efek Januari di antara pasar modal di negaranegara Eropa, Australia, Jepang dan Singapura. Beberapa penjelasan menunjukkan adanya efek Januari yang terjadi di pasar modal, tetapi hampir semuanya tidak memberikan keterangan yang pasti. Penjelasan mengenai pengujian efek Januari terutama menyangkut hipotesis tentang kerugian pajak penjualan (tax-loss selling). Hipotesis ini menyatakan tidak adanya efek musiman bulanan dalam keadaan tidak adanya pajak capital gain di pasar modal yang bersangkutan. Namun demikian, ada bukti-bukti munculnya efek Januari dalam sistem pasar modal (Kato and Schallheim, 1985) dan ada bukti-bukti yang menentang efek Januari ketika konsep pajak diterapkan (Mehdian and Perry, 2002). Kenyataan bahwa tidak semua pasar modal menentukan pajak dalam capital gain. Hal ini perlu diperhatikan berkait dengan efek musiman, walaupun masalah tersebut bukan sebagai fokus dalam penelitian ini.

Efek musiman yang terjadi di suatu pasar modal dapat mempengaruhi keadaan pasar modal yang lain dalam suatu wilayah yang terintegrasi. Integrasinya suatu pasar modal di suatu wilayah antara lain ditandai oleh efek yang beruntun dari peristiwa yang terjadi di pasar modal di suatu negara akan berakibat terhadap pasar modal di negara lain. Peristiwa di suatu negara akan saling berpengaruh terhadap peristiwa yang terjadi di negara-negara lain, khususnya negaranegara yang berada dalam satu kawasan. Pengaruh ini dapat bersifat pengaruh negatif mapun positif. Pengaruh negatif menunjukkan bahwa perubahan positif harga saham di negara asal (origin) akan diikuti perubahan negatif harga saham di negara lain. Artinya, apabila harga saham di negara asal meningkat maka harga saham di negara lain menurun. Sebaliknya, pengaruh positif menunjukkan bahwa perubahan meningkatnya harga saham di pasar modal suatu negara diikuti oleh naiknya harga-harga saham di pasar modal negara-negara lain. Di lihat dari segi sifatnya, perubahan harga dapat bersifat tetap maupun musiman. Perubahan musiman menunjukkan bahwa perubahan yang terjadi berlaku pada musimmusim tertentu.

Dalam pasar modal yang terintegrasi bagi daerah geografi tertentu khususnya daerah Asia Tenggara, penelitian ini memfokuskan pada pengaruh penularan perubahan musiman suatu pasar modal di lima negara ASEAN (Indonesia, Malaysia, Thailand, Philipina dan Singapura). Kawasan ASEAN sebagai daerah yang dipilih karena negara-negara ini berdekatan secara ekonomi dan geografi. Pemilihan lima negara ASEAN ini merupakan penetapan yang ideal untuk menentukan adanya efek penularan (contagion effect) karena daerah tersebut terdiri dari pasar modal yang mempunyai karakteristik yang serupa yaitu masih kurangnya penyebaran informasi dan transparasi, dengan demikian pelaksanaan monitoring ke atas investasi dalam pasar modal ini sangat mahal. Ketika fakta-fakta pola return muncul dalam pasar modal yang asli (origin), pasar modal yang lain meng- 
ikutinya (terjadi efek penularan) sebab investor di pasar modal yang lain dalam daerah yang sama menemukan hal itu lebih mudah dan lebih murah untuk beraksi berdasarkan pola dalam pasar modal yang asli daripada meneliti atau mencari informasi yang diperlukan.

Tujuan utama dari penelitian ini adalah untuk menyelidiki ada atau tidak pengaruh musiman dalam pasar modal tertentu menjalar (contagious) ke pasar modal yang lain. Besarnya atau kuat tidaknya pengaruh musiman yang terjadi di pasar modal ASEAN juga akan dikaji dalam penelitian ini. Tujuan penelitian ini dimotivasi oleh munculnya bukti-bukti dari integrasi dalam pasar keuangan internasional. Mobilitas modal ini berlaku secara bebas sebagaimana mekanisme integrasi ekonomi seperti yang terjadi di Uni Eropa (European Union), North American Free Trade Area (NAFTA) untuk diterapkan di kawasan ASEAN Free Trade Area (AFTA) atau yang baru berlaku tahun 2010 ini adalah ChinaASEAN Free Trade Area (CAFTA). Dalam kasus di kawasan Asia Tenggara, penelitian ini menemukan bahwa fluktuasi pasar modal kebanyakan dipengaruhi oleh pasar modal regional dibanding pasar modal negaranegara maju. Salah satu penyebanya berasal dari efek potensial kontagion dari perubahan musiman (seasonality) pasar modal yang didifinisikan sebagai pola return yang tinggi secara abnormal dalam suatu pasar modal Negara asal (leader/origin) yang mencetuskan pola abnormal return yang tinggi serupa di pasar modal yang lain. Dengan kata lain, hubungan leader-follower memberikan investor dalam pasar modal follower untuk mengeksploitasi efek seasonality dengan observasi trend pada pasar modal leader.

\section{KAJIAN PUSTAKA}

Efek Penularan (Contagion Effect)

Fenomena efek penularan saat ini merupakan suatu topik yang sedang hangat dibahas para ahli. Dari berbagai penelitian yang telah dilakukan, dapat diketahui bahwa efek penularan dapat terjadi melalui 2 cara, yaitu karena ada hubungan dagang (trade links) dan kesamaan kondisi dan kebijakan makroekonomi. Gerlach and Smets (1998) mengembangkan suatu model yang dapat menjelaskan mekanisme efek penularan melalui hubungan perdagangan. Didalam modelnya, serangan terhadap suatu mata uang menyebabkan mata uang tersebut terdepresiasi sehingga dapat meningkatkan daya saing produknya. Peningkatan daya saing ini berarti penurunan ekspor bagi negara-negara pesaingnya, sehingga dapat mengakibatkan negara pesaingnya mengalami defisit transaksi berjalan, penurunan cadangan devisa secara bertahap, dan pada akhirnya menghasilkan suatu serangan terhadap mata uangnya.

Disamping memberikan efek penularan pada negara pesaingnya, krisis mata uang juga dapat memberikan efek penularan pada negara mitra dagangnya. Krisis yang melanda suatu negara mengakibatkan depresiasi, sehingga harga barang ekspornya menjadi turun. Bagi negara mitra dagangnya, hal ini berarti penurunan harga barang impor yang dapat mendorong penurunan tingkat inflasi dan permintaan uang beredar. Untuk melindungi mata uangnya, pelaku ekonomi pada negara mitra dagang dapat melakukan swap yang mengakibatkan terkurasnya cadangan devisa yang dikuasai bank sentral. Dalam kondisi cadangan devisa yang menurun, krisis mata uang dapat timbul karena cadangan devisa tidak cukup kuat menyerap serangan pekulasi para pelaku pasar uang.

Kesamaan kondisi makroekonomi juga dapat memunculkan efek penularan apabila salah satu negara mengalami krisis. Krisis yang diakibatkan oleh kesamaan makroekonomi ini pada umumnya dipicu oleh para pelaku pasar uang. Shiller (1995), mengembangkan model untuk menjelaskan 
salah satu mekanisme efek penularan melalui kesamaan kondisi makroekonomi. Menurutnya, para pelaku pasar uang sebenarnya banyak menerima informasi yang sama (melalui alat komunikasi yang sama, seperti Reuter), sehingga suatu reaksi atas sepotong informasi yang baru dapat menyebar ke seluruh dunia dalam waktu yang singkat dan menyampaikan pesan pada pelaku pasar internasional untuk melakukan reaksi yang sama. Kemungkinan ini dapat terjadi apabila respons yang ditempuh sebagian pelaku pasar mampu mengatasi keyakinan pasar dan merubah ekspektasi pasar. Jadi, serangan terhadap suatu mata uang dapat merangsang pelaku pasar internasional untuk melakukan langkah yang sama. Demikian pula sebaliknya, reaksi yang diambil pelaku pasar internasional dapat mendorong pelaku pasar lokal untuk melakukan langkah yang sama.

Berkaitan dengan krisis yang saat ini sedang melanda Asia, walaupun fundamental ekonomi memegang peranan yang penting, sebagaimana tampak dari perbedaan fundamental ekonomi negara yang terkena krisis dengan yang tidak terkena krisis, namun efek penularan diduga ikut berperan sebagai pemicu terjadinya krisis. Hal ini dapat dilihat dari tenggang waktu terjadinya serangan yang beruntun dalam waktu yang relatif sangat singkat, berturutturut dari Thailand, Philippines, Malaysia, Indonesia, dan terakhir Korea. Sementara itu, serangan dari para pelaku pasar ini juga melanda negara-negara NIEs lainnya, namun serangan ini relatif dapat diredam dengan baik.

Untuk membuktikan dugaan bahwa efek penularan ikut memberikan kontribusiterhadap terjadinya krisis, dalam paper ini digunakan model probit. Model probit banyak dipakai untuk data kualitatif yang mencerminkan suatu pilihan alternatif. Dalam model ini, model probit mencerminkan ada 2 alternatif bagi pelaku pasar uang, yaitu apakah akanmelakukan serangan atau tidak, dengan mempertimbangkan data fundamental ekonomi dan data serangan pada mata uang lain. Untuk mentransformasikan alternatif pilihan dari bentuk kualitatif ke kuantitatif, model probit menggunakan fungsi distribusi normal kumulatif, sehingga nilainya berkisar dari 0 ke 1 . Dengan kata lain, model probit tersebut menyatakan besarnya kemungkinan pelaku pasar melakukan serangan.

\section{Efek Kalender}

Selain kinerja emiten, rumor, sentimen, dan kondisi ekonomi, kepercayaan investor atas siklus peristiwa di pasar saham juga bisa mempengaruhi pergerakan harga saham. Ada teori yang mengatakan bahwa pada hari atau bulan tertentu dalam setiap tahun, harga saham akan cenderung bergerak lebih fluktuatif. Teori ini disebut efek kalender (calendar effect). Efek kalender ini bisa menjadi peluang atau ancaman buat investor. Sebagian teori-teori itu tidak memiliki bukti yang cukup. Tapi, ada pula data-data statistik yang mampu membuat para investor saham mempercayainya. Ada beberapa teori yang masuk kategori efek kalender ini. Di antaranya efek Senin (Monday effect), efek akhir pekan (weekend effect), efek Oktober (October effect), efek liburan (holiday effect), dan efek Januari (January effect).

Teori efek Senin mengatakan bahwa pergerakan bursa saham pada hari Senin akan mengikuti tren pada hari Jumat pekan sebelumnya. Karenanya, jika indeks saham menguat pada hari Jumat, ia akan melanjutkan penguatannya di hari Senin pekan berikutnya. Beberapa studi telah membuktikan teori ini. Tapi, hingga kini, tidak ada yang bisa menerangkan mengapa efek Senin bisa terjadi. Tetapi, ada efek akhir pekan atau weekend effect yang agak berlawanan dengan teori pertama tadi. Teori ini bilang bahwa keuntungan saham di hari Senin akan 
lebih rendah dibandingkan keuntungan pada hari Jumat pekan sebelumnya.

Efek akhir pekan ini sering terjadi. Beberapa pengamat lantas berusaha memberikan penjelasan tentang perilaku bursa saham ini. Salah satunya, perusahaanperusahaan cenderung mengumumkan kabar buruk setelah pasar tutup pada hari Jumat. Tujuannya adalah untuk meredam dampak kabar buruk itu pada harga sahamnya di bursa. Akibatnya, ketika pasar dibuka pada hari senin, penguatan indeks akan tertahan, atau bahkan turun.

Ada beberapa teori yang masuk kategori efek kalender atau calendar effect. Di antaranya adalah efek Senin (Monday effect), efek akhir pekan (weekend effect), efek Oktober (October effect), efek liburan (holiday effect), dan efek Januari (January effect). Tapi, tidak semua teori-teori tersebut benar-benar terjadi atau terbukti. Sebagai contoh, berikut merupakan penjelasan mengenai efek Oktober atau October effect. Efek Oktober adalah teori yang mengatakan bahwa indeks bursa saham akan cenderung turun pada bulan Oktober. Dasarnya, sebagian investor akan merasa cemas pada bulan Oktober karena di masa lalu peristiwa kehancuran pasar saham selalu terjadi pada bulan ini. Sebut saja peristiwa Black Monday, Black Tuesday, dan Black Thursday yang semuanya terjadi pada bulan Oktober 1929. Peristiwa itu kemudian diikuti oleh depresi ekonomi hebat di seluruh dunia (Great Depression). Selain itu, pada tanggal 19 Oktober 1987, bursa saham juga mengalami kehancuran (great crash). Waktu itu, indeks Dow Jones Industrial Average (DJIA) di Amerika Serikat (AS) longsor 22,6\% dalam satu hari. Namun, saat ini, momok efek Oktober itu sudah mulai memudar. Teori itu hanya memberikan efek psikologis kepada sebagian kecil investor saja. sementara, peristiwa riilnya sendiri sudah sangat jarang terjadi. Contoh yang paling jelas adalah yang terjadi pada bulan
Oktober 2007 ini. Indeks DJIA menguat, sementara indeks S\&P 500 telah menembus rekor baru. Di Indonesia, indeks harga saham gabungan (IHSG) juga sudah menembus angka keramat 2.500. Hal yang serupa juga terjadi pada teori efek Januari atau January effect. Sejatinya, teori ini bilang bahwa harga saham-saham akan cenderung meningkat pada bulan Januari. Ini terjadi karena investor akan cenderung memburu saham-saham yang harganya telah jatuh pada akhir Desember tahun sebelumnya. Kejatuhan harga-harga saham di akhir tahun itu sendiri terjadi karena para investor menjual saham-sahamnya demi membukukan kerugian dan mengurangi kewajiban pajak. Namun, saat ini, peristiwa itu sudah jarang terjadi karena para investor telah melakukan penyesuaian.

\section{Efek Perubahan Musiman}

Efek perubahan musiman banyak didasarkan pada pola perubahan efek Januari. Penelitian efek Januari terutama mengacu pada kajian Rozeff and Kinney (1976). Mereka menggunakan rata-rata return bulanan pada NYSE (New York Stock Exchange) setelah periode 70 tahun antara 1904 sampai 1974. Kajian mereka menemukan bahwa kecuali periode 1929 sampai 1940 rata-rata return dalam bulan Januari adalah lebih tinggi dibanding bulan-bulan lain. Dalam periode penelitian yang lebih pendek antara tahun 1963 hingga 1979, Keim (1983) masih menemukan bukti efek Januari dari saham-saham yang diperdagangkan di NYSE. Haugen dan Jorion (1996) meneliti efek Januari yang terjadi dari tahun 1926 sampai tahun 1993. Mereka menemukan bahwa efek Januari yang terjadi menunjukkan kesan tidak adanya tanda yang signifikan atas munculnya efek Januari tersebut. Pendapat ini sangat didukung oleh hampir semua buki akhir-akhir ini yang ditemukan oleh penelitian yang lain. Kajian terhadap efek Januari secara relatif kurang 
tegas (rigorous), tetapi di sisi lain adanya anomali pasar masih mendukung keberadaan efek Januari. Sebagai contoh, bukti yang ditemukan oleh Gultekin and Gultekin (1983) menyatakan bahwa pasar modal masih menyadari dengan adanya efek Januari sebagai suatu fenomena internasional. Mereka juga menemukan secara signifikan kegiatan pasar yang tidak biasa (unusual market activity) pada bulan Januari di Amerika Serikat seperti pada beberapa negara-neaga Eropa, Australia, Jepang dan Singapura. Dengan bukti yang mendukung efek Januari dirasa sudah cukup untuk ditetapkan bahwa efek Januari merupakan penjelasan anomali pasar.

Penjelasan-penjelasan yang menerangkan efek Januari, hampir semuanya menguji hipotesis tax-loss selling. Dalam penjelasan hipotesis tax-loss selling sendiri, Reinganum (1983), Keim (1983), Badrinath and Lewellen (1991), dan Dyl and Maberly (1992), menegaskan bahwa para investor yang memegang saham-saham kurang baik akan mengambil posisi short (beli) pada akhir tahun untuk mengurangi pajak neto dari capital gain. Pada rapat umum pemegang saham tahunan, sebagai investor akan masuk kembali ke pasar untuk menciptakan tekanan harga lebih tinggi sehingga abnormal retun terjadi selama bulan itu.

Hipotesis tax-loss selling menyatakan bahwa efek Januari atau efek musiman seharusnya bukan fenomena dalam hadirnya pajak dalam capital gain seperti kasus di Malaysia, Singapura, Thailand, Indonesia dan Philipina, dan beberapa negara lain. Menggunakan indeks 6 sektor dari Bursa Malaysia, Yong (1991) menemukan hasil yang konsisten dengan hipotesis tax-loss selling sebagai anomali pasar tidak ada di pasar modal Malaysia. Kajian yang dilakukan oleh Abd-Rahim et al. (2005) menggunakan data lebih mutakhir tahun 1980 sampai 2004, menemukan bukti kuat adanya efek Januari/Pebruari pada pasar modal yang sama. Penemuan yang kontradiksi ini adalah bukan suatu yang mengherankan sebab hubungan antara efek Januari dan hipotesis tax-loss selling agak kontroversial.

Kato and Schallheim (1985) menemukan bahwa efek Januari muncul dalam sampel saham perusahaan-perusahaan di Jepang meskipun tidak ada sistem pajak capital gain di negara tersebut. Jones et al. (1987) menemukan efek Januari di Amerika Serikat telah muncul sejak periode pre-tax. Bukti argumen yang menentang tax-loss selling dalam suatu negara yang mengenakan pajak capital gain tidak berarti dapat diabaikan. Dalam suatu sampel perusahaanperusahaan yang terdaftar di NYSE dan AMEX (American Stock Exchange) selama periode tahun 1888 sampai 1992, Cox and Johnston (1998) menemukan bahwa sahamsaham dengan potensi tax-loss selling yang tinggi tidak menunjukkan abnormal return dalam bulan Januari. Dengan menggunakan indeks pasar seperti indeks Dow Jones, NYSE Composite dan S \& P 500, Mehdian and Perry (2002) juga menemukan bahwa setelah krisis pasar modal tahun 1987 return saham bulan Januari tidak lebih berbeda secara signifikan dengan return saham bulan-bulan yang lain. Jadi isu ini masih jauh dari penyelesaian secara menyeluruh, sebab secara jelas ada penjelasan-penjelasan lain terhadap efek Januari di samping hipotesis tax-loss selling.

Berdasarkan tinjauan pustaka dan fenomena yang terjadi di kawasan Asia Tenggara, hipotesis penelitian ini adalah terdapat efek penularan (contagion effect) perubahan musiman yang terjadi di pasar modal dalam kawasan negara-negara ASEAN". Efek contagion ini terjadi karena adanya integrasi pasar modal di kawasan tersebut.

\section{METODE PENELITIAN}

Populasi dan Sampel

Penelitian ini akan dilakukan di kawasan negara-negara ASEAN. Sampel 
penelitian meliputi negara Indonesia, Malaysia, Thailand, Philipina dan Singapura. Negara ASEAN lainnya seperti Negara Brunei Darussalam, Myanmar, Vietnam, Laos dan Kamboja tidak dijadikan sampel penelitian ini karena di Negaranegara tersebut belum berkembang pasar modalnya sehingga datanya tidak cukup. Alasan pengambilan sampel bagi lima Negara ASEAN di atas (Indonesia, Malaysia, Thailand, Philipina dan Singapura) karena perkembangan pasar modal di kelima negara tersebut relative sama meskipun pasar modal di Singapura lebih meninjol.

\section{Metode Pengambilan Data}

Untuk menguji efek perubahan musiman (seasonality) harga saham di pasar modal yang dijadikan sampel, kajian ini menggunakan data makro berupa indeks komposit harga saham di masing-masing pasar modal mulai tahun 1990 sampai tahun 2007. Indeks pasar modal ke lima negaranegara ASEAN tersebut yaitu Kuala Lumpur Composite Index (KLCI) untuk Malaysia, Jakarta Composite Index (JCI) untuk Indonesia, Stock Exchange of Thailand Composite Index (SET) untuk Thailand, Singapore All Equities (SAE) untuk Singapura, dan the Philippines Stock Exchange Composite Index (PCI) untuk Philipina.

Pemilihan data berupa indeks komposit semacam ini adalah serupa dengan data yang pernah digunakan oleh penelitipeneliti terdahulu (Abd-Rahim et al, 2006; dan Medhdian and Perry, 2002). Pendekatan ini memberikan keuntungan seperti dapat diminimalkannya masalah struktur mikro yang dimasukkan dalam saham individual dan atau saham institusi (Johnston and Cox, 2002). Di samping itu, kesan perubahan musiman (seasonality) menjadi lebih mudah dideteksi (Pandey, 2002) dan menghindari masalah yang berkait dengan formasi portofolio ( $\mathrm{Gu}$ and Simon, 2004). Indeks komposit yang digunakan dalam penelitian ini berupa indeks komposit pada penutupan bulanan, yang didifinisikan sebagai indeks harga pada penutupan perdagangan hari terakhir pada bulan yang bersangkutan. Data tersebut diperoleh dari Thompson Data stream dan publikasi pasar modal, khusunya yang tersedia di Bursa Efek Indonesia dan Bursa Saham Malaysia. Pemilihan setiap negara didasarkan pada indeks pasar modal yang bersangkutan karena indeks tersebut dapat dipertimbangkan sebagai suatu representasi yang tepat bagi kondisi pasar modal di Negara tersebut. Di samping itu berdasarkan ketersediaan data yang ada bagi penelitian ini, maka jangka waktu penelitian adalah mulai bulan Januari 1990 sampai Desember 2007.

\section{Metode Analisis Data}

Perubahan musiman (seasonality) yang terjadi di pasar modal negara-negara ASEAN saling berkaitan antara satu negara dengan negara lainnya. Oleh karena itu, kejadian di suatu negara mempunyai efek perubahan terhadap negera lainnya. Efek ini sering dinamakan sebagai contagion effect (efek kontagion) atau efek penularan dimana kejadian baik atau buruk di suatu negara akan menular ke Negara-negara lainnya, khususnya yang terjadi di Negara-negara ASEAN. Untuk mengetahui efek kontagion yang terjadi di Negara-negara ASEAN tersebut, analisis data dalam penelitian ini menggunakan metode regresi linier berganda. Beberapa langkah untuk menganalisis data diuraikan berikut ini (Abd-Rahim et al, 2006).

\section{Menghitung return saham bulanan}

Return saham merupakan hasil investasi saham yang diharapkan diperoleh investor baik berupa dividen maupun capital gain. Pada penelitian ini, return yang diperhitungkan terutama berupa capital gain bulanan. Untuk seluruh periode penelitian, 
return bulanan bagi tiap-tiap indeks pasar modal dihitung sebagai berikut:

$\mathrm{R}_{\mathrm{it}}=\frac{\mathrm{PI}_{\mathrm{it}}-\mathrm{PI}_{\mathrm{it}-1}}{\mathrm{PI}_{\mathrm{it}-1}} \times 100 \%$

di mana PI $_{i, t}$ adalah harga penutupan dari indeks pasar modal i pada bulan t.

\section{Menghitung rata-rata return bulanan}

Untuk mengidentifikasi perubahan musiman bulanan, penelitian ini akan menghitung rata-rata return setiap pasar modal untuk tiap bulan $\mathrm{t}$, dengan formula:

$\mathrm{R}_{\mathrm{it}}=\frac{\sum_{\mathrm{y}=1}^{\mathrm{n}_{\mathrm{i}, \mathrm{t}, \mathrm{y}}}}{\mathrm{n}_{\mathrm{i}}}$

di mana y adalah tahun $1990, \ldots, 2007, \mathrm{t}=$ bulan Januari, ..., atau Desember, $\mathrm{n}$ adalah jumlah hari dari return bulanan yang diperhitungkan dan i adalah indeks pasar modal berdasarkan negara masing-masing.

\section{Menguji adanya efek seasonality dan contagion}

Guna mencapai tujuan penelitian ini, selanjutnya analisis data ditujukan untuk menguji adanya efek perubahan musim (seasonality) dan efek kontagion. Pengujian yang dilakukan melalui beberapa tahap. Tahap pertama digunakan untuk menetapkan langkah-langkah guna menguji adanya efek seasonality. Tahap kedua, kemudian kajian ini menggunakan pendekatan Granger causality untuk menyelidiki adanya hubungan jangka pendek (berdasarkan return) di antara return-return dari sampel pasar modal. Langkah ini dilakukan untuk menentukan pasar modal mana yang bereaksi sebagai negara penyebab (origin) dan negara mana yang bertindak sebagai negara yang terpengaruh. Langkah berikutnya, penelitian ini menggunakan Granger causality untuk menguji adanya efek contagion. Untuk menguji adanya efek seasonality dan juga efek contagion akan digunakan metode time seri regresi linier berganda. Sedangkan untuk memastikan bahwa datanya cukup untuk analisis time seri, maka analisis akan dimulai dengan menguji dua asumsi analisis time seri kuadrat terkecil (least square) yaitu tes normalitas dari distribusi data dan tes keseimbangan (stationary) data.

Penelitian ini menggunakan model regresi yang mula-mula dipakai oleh Pietranico and Riepe (2004), dan Abd. Rahim et al (2006) untuk mendeteksi adanya efek seasonality dengan formula sebagai berikut:

$\mathrm{R}_{\mathrm{i}, \mathrm{t}}=\alpha_{\mathrm{i}}+\beta_{1}\left(\mathrm{D}_{\mathrm{i}, \mathrm{t}}^{\mathrm{s}}\right)+\mathrm{e}_{\mathrm{i}, \mathrm{t}}$

di mana $\mathrm{R}_{\mathrm{i}, \mathrm{t}}$ adalah return bulanan pada indeks tahun $\mathrm{i}$ pada akhir bulan $\mathrm{t}, \quad \alpha_{\mathrm{i}}$ konstanta sebagai intersep, $\beta_{1}=$ koefisien ramalan dari faktor penjelas, sedangkan $\mathrm{D}_{\mathrm{i}, \mathrm{t}}^{\mathrm{s}}$ adalah variabel boneka (dummy variable) dari seasonality bulanan bagi indeks pasar, dan $\mathrm{e}_{\mathrm{i}}$ adalah error term untuk indeks tahun i. Variabel boneka $\mathrm{D}^{\mathrm{s}}$ sama dengan 1 jika bulan s adalah bulan seasonal bagi masingmasing pasar modal, dan 0 jika terjadi sebaliknya. Koefisien variabel boneka adalah positif signifikan jika return secara berseri menggambarkan pola abnormal return yang positif dalam seasonal bulanan. Oleh karena itu, variabel boneka (dummy varable) pada persamaan (3) di atas dapat diuraikan dalam persamaan (4) berikut ini:

$\mathrm{D}^{\mathrm{s}}=1$ jika bulan $\mathrm{s}$ adalah bulan musiman (seasonality) bagi tiap-tiap pasar modal, dan sama dengan nol jika terjadi sebaliknya

Model time series yang kedua mengacu kepada model yang telah digunakan oleh Kanas (2005) dan Narayan et al. (2004) untuk mencari efek contagion secara umum yang berlaku di negara-negara ASEAN dengan menggunakan pengujian Granger causality. Dengan pengujian Granger ini dapat digunakan untuk 
mengidentifikasi negara mana yang bertindak sebagai leader atau origin dari efek contagion atas return di negara asal. Model regresi time series secara umum dapat ditulis sebagai berikut:

$$
\begin{aligned}
\mathrm{R}_{\mathrm{t}}^{\mathrm{H}}= & \alpha^{\mathrm{A}}+\beta_{1}^{\mathrm{H}}\left(\mathrm{D}_{\mathrm{t}}^{\mathrm{H}}\right)+\beta_{2}\left(\mathrm{R}_{1, \mathrm{t}}^{\mathrm{O}}\right) \\
& +\ldots+\beta_{5}\left(\mathrm{R}_{5, \mathrm{t}}^{\mathrm{O}}\right)+\varepsilon_{\mathrm{t}}^{\mathrm{H}}
\end{aligned}
$$

di mana $R_{t}$ adalah return dari indeks pada akhir bulan $t, \alpha^{A}$ adalah intersep bagi saham pasar modal negara asal, $O$ adalah pasar modal yang diidentifikasi sebagai origin (pasar modal mula-mula/asal) dari efek contagion, $H$ adalah negara di mana pasar modalnya diidentifikasi secara potensial akan terpengaruh oleh negara origin, $\beta$ adalah besarnya koefisien pengaruh (respon) dari return pasar modal negara $\mathrm{H}$ kepada masing-masing return pasar modal negara O, $D^{H}$ adalah variabel boneka bulan seasonal bagi masing-masing pasar modal dan $\varepsilon$ adalah error term bagi pasar modal. Model dalam persamaan 5 memprediksi return bulanan dari pasar modal negara tertentu yang dijelaskan tidak hanya ada pola seasonal bulanan, tetapi juga oleh pola return di pasar modal selain negara ASEAN yang telah diidentifikasi memicu pola seperti negara origin. Dengan kata lain, pola return pasar modal negara "origin" tertentu ditularkan atau contagious kepada pasar modal lain di kawasan tersebut. Sebagai contoh, return di pasar modal Malaysia tidak hanya disebabkan oleh abnormal return bulan Desember/Pebruari tetapi juga dipengaruhi oleh return bulanan saham di pasar modal negara-negara Thailand, Indonesia, Philippina, dan Singapura. Namun demikian, persamaan 5 hanya sesuai untuk merepresentasikan hubungan antara pola pasar modal di lima pasar modal secara umum. Untuk mengkaji hubungan secara spesifik berkait dengan seasonality, persamaan 5 dimodifikasi untuk menggabungkan hanya return bulanan yang telah diidentifikasi untuk menunjukkan efek seasonality sebagai berikut:

$$
\mathrm{R}_{\mathrm{t}}^{* \mathrm{H}}=\alpha^{\mathrm{H}}+\beta_{1}\left(\mathrm{R}_{1, \mathrm{t}}^{* \mathrm{O}}\right)+\ldots+\beta_{5}\left(\mathrm{R}_{5, \mathrm{t}}^{* \mathrm{O}}\right)+\varepsilon_{\mathrm{t}}^{\mathrm{H}}
$$

Sebelum analisis dilanjutkan dengan tes seperti persamaan 6, isu yang diperlukan untuk menyelesaikannya adalah identifikasi seasonal bulanan yang dapat berubah dari satu pasar modal ke pasar modal yang lain. Kasus seperti ini pernah diteliti di Malaysia di mana efek seasonality-nya tidak berlaku secara tetap. Efek seasonality ini telah berubah dari Januari periode tahun 19701988 yang diteliti oleh Yong (1991) menjadi efek Januari/Pebruari selama periode tahun 1980-2000 yang diteliti oleh Abd-Karim (2002) sebelum dimantapkan untuk efek Desember/Pebruari pada periode tahun 1992 hingga 2002 yang diteliti oleh Pandey (2002) dan periode 1988-2004 oleh AbdRahim (2006). Secara keseluruhan, tendensi di Malaysia menuju efek Pebruari karena Malaysia lebih mudah dikaitkan dengan efek Tahun Baru China (Chinese New Year).

\section{HASIL ANALISIS DAN PEMBAHASAN Deskriptif Statistik}

Deskriptif statistik menggambarkan keadaan statistik sampel penelitian yang digunakan, khususnya mengenai nilai minimum dan maksimum return atas sahamsaham yang dijadikan sampel di negaranegara ASEAN. Keadaan nilai minimum dan maksimum return saham di Pasar Modal negara-negara ASEAN ditunjukkan pada Tabel 1. 
Jurnal Siasat Bisnis Vol. 14 No. 1, April 2010 Hal: 1-18

Tabel 1: Deskriptif Statistik Return Saham di Pasar Modal Negara-negara ASEAN

\begin{tabular}{lccccc}
\hline \multicolumn{1}{c}{ Negara } & Bulan & $\begin{array}{c}\text { Return } \\
\text { Minimum }\end{array}$ & Bulan & $\begin{array}{c}\text { Return } \\
\text { Maksimum }\end{array}$ & Return Total \\
\hline Malaysia & Agustus & $-0,028$ & February & 0,041 & 0,150 \\
Thailand & Maret & $-0,027$ & January & 0,042 & 0,119 \\
Indonesia & Agustus & $-0,028$ & Desember & 0,092 & 0,222 \\
Singapura & Agustus & $-0,021$ & Desember & 0,31 & 0,091 \\
Philipina & Agustus & $-0,045$ & Desember & 0,048 & 0,088 \\
\hline
\end{tabular}

Sumber: Data diolah.

Tabel 1 menunjukkan nilai minimum dan maksimum serta total return saham bulanan selama periode analisis yaitu bulan Januari 1990 hingga bulan Desember 2007 atau selama 18 tahun. Seperti yang telah ditunjukkan pada Tabel 1, nilai return saham minimum dan maksimum yang diidentifikasi terjadi pada bulan-bulan tertentu, yaitu bulan dengan efek musim yang mungkin terjadi dimana setiap pasar modal berada pada return bulanan rata-rata tertinggi. Adapun penghitungan rata-rata return saham bulanan tersebut dilakukan selama periode penelitian (18 tahun), yaitu:

$\mathrm{R}_{\mathrm{i}, \mathrm{t}}=\frac{\sum_{\mathrm{v}=1}^{\mathrm{n}} \mathrm{R}_{\mathrm{i}, \mathrm{t}, \mathrm{v}}}{\mathrm{n}_{1}}$

di mana y adalah tahun $1990, \ldots, 2007, \mathrm{t}=$ bulan Januari, ..., atau Desember, dan notasi $\mathrm{n}$ adalah jumlah hari dari return bulanan yang diperhitungkan dan i adalah indeks pasar modal berdasarkan negara masingmasing.

Selanjutnya, Tabel 1 juga menunjukkan bahwa semua pasar saham kecuali Thailand secara tetap melaporkan bulan Agustus sebagai bulan dengan pendapatan (return) bulanan rata-rata paling rendah. Bahkan, negara Thailand juga melaporkan pendapatan terendah yang kedua juga pada bulan Agustus (tidak dilaporkan dalam penelitian ini). Namun, keadaan ini ternyata tidak hanya terjadi khusus untuk kawasan ASEAN karena hasil yang sama telah diperoleh dalam penelitian yang dilakukan Abd-Rahim (2006). Beliau menempatkan bulan-bulan sepi di bulan Agustus bagi pasar-pasar saham di Amerika, Inggris, dan Jepang. Kesamaan lainnya melibatkan pola pendapatan dalam lima bulan lainnya, yaitu bulan Januari, Februari, April, Mei, dan Desember dimana semua negara ASEAN tersebut melaporkan pola-pola yang positif. Hasil penelitian ini berbeda dengan Yong (1991) yang telah meneliti pola perubahan musiman di Malaysia. Hasil yang diperolehnya menunjukkan bahwa rata-rata pendapatan bulanan tertinggi/terendah terjadi pada bulan Januari/Maret. Namun demikian, penelitian ini mendukung penelitian yang dilakukan oleh Pandey (2002), dan Abd-Rahim et al. (2006).

Gambaran atau fitur "regionalitas" dari negara-negara ASEAN tersebut dibuktikan dengan korelasi yang secara konsisten positif dan sangat signifikan diantara mereka pada alfa $1 \%(\alpha<0.01)$. Hasil analisis regresi hubungan antar pasar modal negara-negara ASEAN dapat dilihat pada Tabel 2. Dari kelima pasar modal tersebut, Indonesia tampaknya memiliki pasar saham yang memiliki korelasi terkecil dengan pasar saham negara ASEAN lainnya (antara 0.335 sampai 0.412). 
Tabel 2: Koefisien Korelasi Analisis Regresi Pasar Modal Negara-negara ASEAN

\begin{tabular}{lccccc}
\hline \multicolumn{1}{c}{ Negara } & Malaysia & Thailand & Indonesia & Singapura & Philipina \\
\hline Malaysia & 1.000 & & & & \\
Thailand & $0.558^{*}$ & 1.000 & & & \\
Indonesia & $0.335^{*}$ & $0.371^{*}$ & 1.000 & & \\
Singapura & $0.672^{*}$ & $0.612^{*}$ & $0.349^{*}$ & 1.000 & \\
Philipina & $0.551^{*}$ & $0.582^{*}$ & $0.412^{*}$ & $0.639^{*}$ & 1.000 \\
\hline
\end{tabular}

Sumber: Data, diolah

Catatan: *) signifikan pada level $5 \%$

Tabel 3: Hasil Analisis Rgresi Return Bulanan Pasar Modal Domestik terhadap Variabel Boneka Musiman (Seasonality Dummy Month)

\begin{tabular}{lccccc}
\hline Parameter & Malaysia & Singapura & Thailand & Indonesia & Philipina \\
\hline$\alpha$ & 0.0004 & 0.0025 & 0.0061 & 0.0072 & 0.0017 \\
& $(0.0581)$ & $(0.5122)$ & $(0.0782)$ & $(0.9093)$ & $(0.2123)$ \\
$\beta_{\mathrm{SD}}$ & 0.0481 & 0.0223 & 0.0509 & 0.0621 & 0.0432 \\
& $(3.0222)^{* * *}$ & $(1.9271)^{*}$ & $(2.8711)^{* * *}$ & $(3.0295)^{* * *}$ & $(2.5581)^{* * *}$ \\
Adjusted-R & 0.0360 & 0.0131 & 0.0319 & 0.0358 & 0.0248 \\
F-Statistik & $9.138^{* * *}$ & $3.745^{*}$ & $8.221^{* *}$ & $9.194 * * *$ & $6.523^{* *}$ \\
Durbin-Watson & 1.8870 & 1.8821 & 1.8634 & 1.7864 & 1.8012 \\
\hline
\end{tabular}

Sumber: Data, diolah

Catatan:

Tiap cell terdiri dari koefisien regresi yang diikuti dengan nilai t-statistik (dalam tanda kurung), dan tanda *, **, dan *** menunjukkan tingkat signifikansi secara beruturut-turut $10 \%, 5 \%$, dan $1 \%$. Tanda alfa $(\alpha)$ adalah intersep dan beta $\left(\beta_{\mathrm{SD}}\right)$ adalah koefisien regresi dari variabel boneka musiman.

Untuk mengukur adanya return abnormal tinggi yang sering terjadi secara berurutan selama bulan-bulan yang sama dalam pasar modal domestik, maka kajian ini meregresikan pendapatan bulanan terhadap variabel boneka (dummy variable) musiman $\left(\beta_{\mathrm{SD}}\right)$. Pada Tabel 3 dilaporkan bahwa koefisien regresi $\left(\beta_{\mathrm{SD}}\right)$ dari variabel boneka musiman adalah sangat signifikan pada tingkat signifikansi $1 \%$ dan 5\% selain pasar modal Singapura yang hanya signifikan pada level yang $10 \%$. Sementara bukti tentang efek musiman (seasonal effect) sangat jelas terjadi di Malaysia dan Indonesia dengan melihat tingginya koefisien regresi tersebut, yaitu sebesar $(3,0222)$ di Malaysia sebesar $(3,0295)$ di Indonesia. Keadaan tersebut juga terjadi di pasar-pasar modal lainnya selama periode penelitian 18 tahun (1990 sampai 2007).

Keadaan yang lebih penting lagi, menyatakan bahwa semua pasar modal di Kawasan ASEAN menunjukkan efek musiman yang signifikan pada tingkat signifikansi $1 \%, 5 \%$ dan $10 \%$. Hal ini memungkinkan untuk dilakukan langkah selanjutnya yaitu menentukan apakah efek musiman yang terjadi ini berpengaruh langsung atau tidak terhadap masing-masing negara. Di samping itu, jika dilihat dari nilai $\mathrm{R}^{2}$ (koefisien determinasi) yang rendah (1.31\% sampai $3.58 \%)$ menunjukkan bahwa sumbangan variabel-variabel yang digunakan untuk menghitung return saham hanya dapat menjelaskan sebesar $1,31 \%$ hingga $3,58 \%$. Hal ini juga menunjukkan 
lemahnya kesesuaian model sehingga memerlukan lebih banyak variabel untuk menjelaskan pendapatan tersebut. Perhitungan return pasar modal suatu negara yang hanya melibatkan indeks komposit pasar modal negara lain ternyata tidak banyak memberikan sumbangan yang berarti yang ditunjukkan oleh nilai $\mathrm{R}^{2}$ tersebut. Berkaitan dengan hipotesis efek kontagion (efek penularan) yang terjadi merupakan suatu peristiwa khusus dalam pasar tertentu akan mendorong efek yang sama pada pasarpasar lainnya, maka perlu ditentukan dulu pasar manakah yang memberikan dan meningkatkan efek penularan tersebut. Salah satu cara yang digunakan untuk mengetahui efek penularan tersebut dalam penelitian ini adalah dengan melaksanakan uji kausalitas Granger.

Berdasarkan hasil penelitian ini, maka kita dapat mengambil tiga kemungkinan kesimpulan dari kausalitas dua arah terhadap dua negara (bivariate), yaitu antara Malaysia dan Singapura, dan Thailand dengan Singapura. Kesimpulan yang dapat diambil adalah sebagai berikut: Pertama, gerakan di dalam pasar modal Singapura tampaknya mengungguli semua pasar modal ASEAN lainnya kecuali untuk pasar modal Philipina. Hal ini dapat diartikan bahwa pasar modal Singapura harus ditetapkan sebagai lokasi dari "sumber penularan" atau outbreak efek musiman yang terjadi di kawasan ASEAN. Dengan kata lain, untuk mendeteksi efek penularan pasar modal secara musiman, maka return saham-saham yang diperdagangkan di Singapura akan menjadi faktor penjelas untuk return saham-saham di pasar modal Malaysia, Indonesia dan Thailand. Peran utama dari pasar modal Singapura diperkirakan menjadi munculnya kekhususan dan stabilitas pasar modal yang terkait dengan pasar-pasar modal yang ada di kawasan ASEAN tersebut. Kedua, di samping pasar modal Singapura, pasar modal Thailand juga Granger menyebabkan pasar modal Malaysia. Oleh karena itu, pendapatan pada saham (return saham) Thailand juga akan berperan sebagai faktor penjelas untuk return saham yang diperdagangkan di Malaysia. Ketiga, pasar modal Indonesia tampaknya tertinggal dibanding semua pasar-pasar modal ASEAN lainnya kecuali Thailand. Dengan demikian, ketika penentuan efek penularan di Indonesia, maka model regresi harus melibatkan pendapatan pada saham-saham yang diperdagangkan dalam semua negaranegara ASEAN kecuali Thailand. Kesimpulannya, efek-efek penularan musiman akan dideteksi dalam tiga pasar modal yaitu pasar modal Indonesia, Malaysia dan Thailand dan secara umum dapat ditunjukkan dengan penjelasann model regresi sebagai berikut:

$$
\begin{aligned}
\mathrm{R}_{\mathrm{t}}^{\text {INDO }}= & \alpha^{\text {INDO }}+\beta_{1}\left(\mathrm{R}_{\mathrm{t}}^{\mathrm{SNG}}\right) \\
& +\beta_{2}\left(\mathrm{R}_{\mathrm{t}}^{\mathrm{MAS}}\right)+\beta_{3}\left(\mathrm{R}_{\mathrm{t}}^{\mathrm{PHIL}}\right) \\
& +\varepsilon_{\mathrm{t}}^{\text {INDO }} \\
\mathrm{R}_{\mathrm{t}}^{\mathrm{MAS}}= & \alpha^{\mathrm{MAS}}+\beta_{1}\left(\mathrm{R}_{\mathrm{t}}^{\text {THAI }}\right) \\
& +\beta_{2}\left(\mathrm{R}_{\mathrm{t}}^{\mathrm{SNG}}\right)+\varepsilon_{\mathrm{t}}^{\mathrm{MAS}} \\
\mathrm{R}_{\mathrm{t}}^{\text {THAI }}= & \alpha^{\text {THAI }}+\beta_{1}\left(\mathrm{R}_{\mathrm{t}}^{\mathrm{SNG}}\right)+\varepsilon_{\mathrm{t}}^{\text {THAI }}
\end{aligned}
$$

Untuk mempertegas hasil yang diharapkan, setiap model di atas dapat disesuaikan untuk mengontrol bagi pengaruh musiman (model 2) sebagaimana efek lag (jangkauan) seperti model (3) yang dibatasi untuk lag 6 dari return saham di pasar modal yang diidentifikasikan sebagai sumber atau asal dari efek penularan yang terjadi. Dari model di atas, model (1) merupakan presentasi dari versi yang origin.

Hail analisis atas penggunaan variasi tiga model persamaan tersebut ditunjukkan pada Tabel 4 berikut ini. 
Tabel 4: Hasil Regresi Return Bulanan Musiman Pasar Modal Origin

\begin{tabular}{|c|c|c|c|c|c|c|c|c|c|}
\hline Indp. Var & & Indonesia & & & Malaysia & & & Thailand & \\
\hline & Model 1 & $\begin{array}{l}\text { Model } 2 \\
\end{array}$ & Model 3 & Model 1 & Model 2 & Model 3 & Model 1 & Model 2 & Model 3 \\
\hline Konstanta & $\begin{array}{c}0.018 \\
(1.779)\end{array}$ & $\begin{array}{c}0.006 \\
(0.789)\end{array}$ & $\begin{array}{c}-0.000 \\
(-0.004)\end{array}$ & $\begin{array}{c}0.002 \\
(0.437)\end{array}$ & $\begin{array}{c}-0.003 \\
(-0.621)\end{array}$ & $\begin{array}{c}-0.003 \\
(-0.658)\end{array}$ & $\begin{array}{c}0.003 \\
(0.605)\end{array}$ & $\begin{array}{c}-0.002 \\
(-0.289)\end{array}$ & $\begin{array}{c}-0.002 \\
(-0.338)\end{array}$ \\
\hline $\begin{array}{l}\text { Musim } \\
\text { Dummy }\end{array}$ & & $\begin{array}{c}0.041 \\
(2.153) *\end{array}$ & $\begin{array}{c}0.047 \\
(2.306) *\end{array}$ & & $\begin{array}{c}0.028 \\
(2.568) *\end{array}$ & $\begin{array}{c}0.024 \\
(2.172) *\end{array}$ & & $\begin{array}{c}0.030 \\
(2.120)^{*}\end{array}$ & $\begin{array}{c}0.026 \\
(1.727)\end{array}$ \\
\hline SING & $\begin{array}{c}0.127 \\
(0.718)\end{array}$ & $\begin{array}{c}0.118 \\
(0.674)\end{array}$ & $\begin{array}{c}-0.025 \\
(-0.132)\end{array}$ & $\begin{array}{c}0.734 \\
(8.621)^{* *}\end{array}$ & $\begin{array}{c}0.715 \\
(8.474)^{* *}\end{array}$ & $\begin{array}{c}0.637 \\
(7.335)^{* *}\end{array}$ & $\begin{array}{c}1.005 \\
(11.323)^{* * *}\end{array}$ & $\begin{array}{c}0.980 \\
(11.040)^{* *}\end{array}$ & $\begin{array}{c}0.954 \\
(10.590)^{* *}\end{array}$ \\
\hline SING $_{-1}$ & & & $\begin{array}{c}0.029 \\
(0.152)\end{array}$ & & & $\begin{array}{c}0.032 \\
(0.373)\end{array}$ & & & $\begin{array}{c}0.056 \\
(0.620)\end{array}$ \\
\hline $\operatorname{SING}_{-2}$ & & & $\begin{array}{c}0.186 \\
(0.998)\end{array}$ & & & $\begin{array}{l}-0.029 \\
(-0.335)\end{array}$ & & & $\begin{array}{c}0.196 \\
(2.163)^{*}\end{array}$ \\
\hline $\mathrm{SING}_{-6}$ & & & $\begin{array}{c}-0.040 \\
(-0.212)\end{array}$ & & & $\begin{array}{c}-0.025 \\
(-0.285)\end{array}$ & & & $\begin{array}{c}-0.131 \\
(-1.473)\end{array}$ \\
\hline MALY & $\begin{array}{c}0.197 \\
(1.695)\end{array}$ & $\begin{array}{c}0.198 \\
(1.712)\end{array}$ & $\begin{array}{c}0.211 \\
(1.680)\end{array}$ & & & & & & \\
\hline MALY $_{-1}$ & & & $\begin{array}{c}0.163 \\
(1.303)\end{array}$ & & & & & & \\
\hline MALY $_{-2}$ & & & $\begin{array}{c}-0.056 \\
(-0.450)\end{array}$ & & & & & & \\
\hline MALY $_{-6}$ & & & $\begin{array}{c}0.036 \\
(0.285)\end{array}$ & & & & & & \\
\hline PHIL & $\begin{array}{c}0.351 \\
(3.430)^{* *}\end{array}$ & $\begin{array}{c}0.326 \\
(3.190)^{* * *}\end{array}$ & $\begin{array}{c}0.363 \\
(3.310)^{* * *}\end{array}$ & & & & & & \\
\hline PHIL $_{-1}$ & & & $\begin{array}{c}0.105 \\
(0.977)\end{array}$ & & & & & & \\
\hline PHIL $_{-2}$ & & & $\begin{array}{c}-0.047 \\
(-0.434)\end{array}$ & & & & & & \\
\hline PHIL-6 & & & $\begin{array}{c}0.092 \\
(0.863)\end{array}$ & & & & & & \\
\hline THAI & & & & $\begin{array}{c}0.203 \\
(3.917)^{* *}\end{array}$ & $\begin{array}{c}0.202 \\
(3.950)^{* *}\end{array}$ & $\begin{array}{c}0.209 \\
(3.943)^{* * *}\end{array}$ & & & \\
\hline THAI $_{-1}$ & & & & & & $\begin{array}{c}0.040 \\
(0.758)\end{array}$ & & & \\
\hline THAI $_{-2}$ & & & & & & $\begin{array}{c}0.180 \\
(3.389)^{* * *}\end{array}$ & & & \\
\hline $\mathrm{THAI}_{-6}$ & & & & & & $\begin{array}{c}0.025 \\
(0.475)\end{array}$ & & & \\
\hline $\begin{array}{l}\text { Adjusted- } \\
\mathrm{R}^{2}\end{array}$ & 0.176 & 0.190 & 0.199 & 0.491 & 0.504 & 0.537 & 0.372 & 0.382 & 0.395 \\
\hline $\begin{array}{l}\text { F- } \\
\text { Statistics }\end{array}$ & $16.282 * *$ & $13.579 * *$ & $3.364 * *$ & 104.735 & 73.856 ** & $17.145 * *$ & $128.211^{* *}$ & $67.398^{* * *}$ & $18.052 * *$ \\
\hline D-Watson & 1.932 & 1.941 & 1.951 & 2.196 & 2.154 & 2.240 & 2.050 & 2.040 & 2.043 \\
\hline
\end{tabular}

Catatan: Tiap sel terdiri dari koefisien regresi diikuti oleh nilai t-statistik. Tanda $*$ and $* *$ menunjukkan signifikansi pada level 5\% dan 1\% secara berurutan. Hasil regresi untuk lag 3 sampai lag 5 adalah sama sampai lag 6, oleh karena itu tidak ditunjukkan pada table untuk menghemat ruangan table. Nilai statistik Durbin-Watson mendekati angka $\approx 2.00$, dan hal ini menunjukkan bahwa tidak ada autokorelasi dalam nilai residualnya.

Hasil-hasil pengujian efek kontagion pasar modal Singapura, Malaysia, dan Philipina terhadap return pasar modal Indonesia sebagai bukti yang mendukung hubungan diantara pasar modal tersebut, meskipun hanya bersifat marginal. Artinya, hubungan efek kontagion yang terjadi tidak begitu kuat. Secara spesifik, karena tidak ada return sekarang (current return) dari lag waktu yang berasal dari pasar modal asal (origin) yang signifikan, hal ini menunjukkan bahwa tidak ada efek kontagion yang dibawa oleh 
pasar modal-pasar modal di kawasan ASEAN. Namun demikian, dari keadaan tersebut ada kekecualian yang terjadi pada return sekarang pasar modal Philipina. Dengan kata lain, jika spesifikasi digunakan dalam kajian ini merupakan estimasi yang layak dilakukan dalam efek kontagion, kemudian koefisien dari variabel PHIL yang nampak konsisten dan secara positif signifikan menunjukkan bahwa ada efek kontagion dari musim yang akan datang dari pasar modal Philipina terhadap pasar modal Indonesia.

Untuk dua pasar modal yang lain (Singapura dan Malaysia) hasilnya juga menunjukkan bahwa sungguh-sungguh terdapat efek kontagion yang terjadi pada masa yang bersamaan. Kecuali dalam kasus Singapura untuk lag $2\left(\mathrm{SING}_{-2}\right)$, koefisien $\mathrm{lg}$ dari variabel "SING" tidak pernah signifikan. Penemuan ini memberitahukan kepada kita bahwa pergerakan return saham Singapura mempengaruhi pergerakan sahamsaham Malaysia seperti halnya return saham Thailand secara bersama-sama. Di samping efek kontagion dari Singapura, return saham di pasar modal Malaysia juga dipengaruhi oleh pergerakan untuk lag 2 bulan di pasar modal Thailand. Secara intuisi, penemuan ini menunjukkan bahwa investor-investor di pasar modal Malaysia memiliki keunggulan yang dapat menyandarkan pada kondisi pasar modal di Singapura dan Thailand untuk meramal kondisi harga saham di pasar tersebut. Namun demikian, seperti peraturan perdagangan adalah hanya memberikan penjelasan yang baik jika dipengaruhi oleh pasar modal yang juga menggambarkan abnormal return dalam bulan yang sama seperti yang terjadi pada bulan Desember. Masalahnya adalah, di Malaysia pengaruh musiman dalam kenyataanya terjadi pada bulan Pebruari. Kemudian apakah terjadinya koefisien yang signifikan untuk return lag 2 bulan di Thailand $\left(\mathrm{THAI}_{-2}\right)$ kemudian hal ini hanya sebagai petunjuk bagi para investor?
Untuk menjawab pertanyaan di atas, penelitian ini menggunakan analisis kausalitas Granger yang hanya menggunakan return musiman bulanan sebagai variabel-variabelnya. Secara spesifik, tes tersebut hanya meliputi return pada bulan Pebruari dan Desember dalam kasus Malaysia, dan return pada bulan Januari dan Desember untuk pasar modal lainnya di ASEAN (Indonesia, Singapura, Thailand dan Philipina).

Tidak seperti pada tes pertama, tes kausalitas Granger ini menghasilkan signifikansi tes yang rendah, dan hal ini selalu terjadi hubungan kasualitas yang satu arah (unidirectioanl). Kecuali yang terjadi pada pasar modal Malaysia yang pergerakannya masih didahului oleh pasar modal Singapura dan Thailand, hubungan yang lain kelihatan banyak perubahan. Bahkan untuk yang pertama kali, pasar modal Singapura saat ini didahului oleh pasar modal Philipina. Sama halnya pasar modal Indonesia yang berada pada bagian bawah rantai dalam uji pertama saat ini mengungguli Thailand. Hubunganhubungan tersebut tidak terduga bukan secara keseluruhan karena mereka menegaskan lebih baik pada sifat dari musim dalam pasar-pasar tersebut. Contohnya, pasar modal Malaysia bergerak paling akhir karena musim terjadi pada Februari. Sama dengan Thailand yang didahului oleh Indonesia sebagian besar diakibatkan karena musim dalam negara tersebut terjadi pada bulan Januari.

Untuk mengetahui apakah hubungan yang muncul dari uji kausalitas Granger memiliki arti-arti intuisi tertentu, penelitian ini membentuk dan menjalankan model regresi berikut ini:

$$
\begin{aligned}
\mathrm{R}_{\mathrm{t}}^{* \mathrm{MAS}}= & \alpha^{* \mathrm{MAS}}+\beta_{1}\left(\mathrm{R}_{, \mathrm{t}}^{* \mathrm{SNG}}\right) \\
& +\beta_{2}\left(\mathrm{R}_{\mathrm{t}}^{* \mathrm{THAIL}}\right)+\varepsilon_{\mathrm{t}}^{* \mathrm{MAS}} \\
\mathrm{R}_{\mathrm{t}}^{* \mathrm{SNG}}= & \alpha^{* \mathrm{SNG}}+\beta_{1}\left(\mathrm{R}_{, \mathrm{t}}^{* \mathrm{THAI}}\right)+\varepsilon_{\mathrm{t}}^{* \mathrm{SNG}}
\end{aligned}
$$




$$
\begin{aligned}
\mathrm{R}_{\mathrm{t}}^{* \mathrm{THAI}}= & \alpha^{* \mathrm{THAI}}+\beta_{1}\left(\mathrm{R}_{, \mathrm{t}}^{* \mathrm{INDO}}\right) \\
& +\varepsilon_{\mathrm{t}}^{* \mathrm{THAI}}
\end{aligned}
$$

Karena variabel-variabel yang dipergunakan di dalam Persamaan (4), (5), dan (6) sudah membentuk pengaruh musiman (Model 1), penelitian ini hanya menambahkannya dengan memasukkan efek-efek yang tertinggal (Model 2 yang terbatas pada 6 sisa) dari return pada saham pasar modal untuk penegasan (robustness).

Konsisten dengan hasil dari uji kausalitas Granger, hasilnya ada di terdapat pada Tabel 4 yang secara umum menyediakan bukti yang kuat dari efek penularan terutama dengan memperhatikan pada Malaysia dimana efek musiman sejauh ini diakibatkan karena musim (pola pendapatan) yang berlaku di Singapura dan Thailand. Koefisien-koefisien dari pendapatan bulan musiman dari Singapura dan Thailand adalah positif (kecuali dalam satu kasus) dan signifikan sampai lag 2. Secara intuitif, hasil-hasil tersebut menyebutkan bahwa kinerja abnormal dari pasar-pasar saham di Singapura dan Thailand tidak ditegaskan untuk batas negara mereka. Justru mereka menular dan mempengaruhi pasar modal tetangga, yang dalam kasus ini adalah Malalysia. Dari sudut pandang investasi, hubungan penularan tersebut menunjukkan bahwa selama bulan-bulan musiman Desember dan Februari, harga saham yang diperdagangkan di Malaysia tampaknya telah merespon secara signifikan terhadap kemutakhiran pada dua pendapatan bulan musiman di Singapura dan Thailand. Dengan kata lain, para investor yang efisien di Malaysia harus mampu memenangkan pendapatan besar abnormal pada bulan Desember $_{\mathrm{t}-1} /$ Februari $_{\mathrm{t}}$ berdasarkan pada kinerja dari pasar-pasar modal Singapura dan Thailands sejak Oktober ${ }_{\mathrm{t}-1}$ November $_{\mathrm{t}-1}$, untuk jangka waktu sekarang.
Kami selanjutnya beralih pada hasil untuk pasar modal Singapura dan Thailand. Secara umum, bukti tentang efek penularan dibatasi pada jangka waktu sekarang karena hanya koefsiein dari pendapatan terbaru yang signifikan pada level 5\%, sehingga menunjukkan bahwa efek-efek penularan jika pernah ada hanya terbatas pada bulanbulan musiman kontemporan. Hal ini terbukti sekali di dalam kasus Thailand. $\mathrm{R}^{2}$ yang telah disesuaikan berhasil bahwa pendapatan bulan musiman di Indonesia hanya menjelaskan $4.2 \%$ dari fluktuasi di Thailand. Dengan menambahkan pendapatanpendapatan yang tertunda dari Indonesia mengurangi kekuatan penjelas dari model lebih lanjut untuk level yang tidak signifikan ( $p(F-s t a t)>0.05)$. Singapura juga mengalami pengurangan di dalam $\mathrm{R}^{2}$ yang telah disesuaikan setelah menambahkan pendapatan yang tertunda dari Philipina, tetapi efeknya masih minim (dari 29.3\% sampai $28.8 \%$ ). Kenyataannya hasil semacam ini melibatkan pasr-pasar modal yang memiliki bulan musiman yang sama, yaitu, Desember dan Januari menyebutkan bahwa efek penularan musim dalam pasar saham Philipina dan Singapura lebih berlangsung singkat sementara musim di Indonesia pada pasar saham Thailand bersifat mencurigakan. Sebaliknya, efek penularan dari musim pasar saham yang berlangsung dari Singapura dan Thailand ke Malaysia sangatlah berarti karena penyebab dimulai dua tahun sebelumnya. Dengan kata lain, para investor di Malaysia dapat memprediksikan dan sehingga dengan demikian menggunakan musim dalam t bulan dengan meneliti fluktuasi pendapatan di Thailand dan Singapura yang bermula dari bulan t-2 dan seterusnya.

\section{PENUTUP}

Penelitian ini mengkaji masalah mengenai efek penularan (kontagion) musiman di dalam pasar saham Malaysia sama sperti empat pasar ekuitas yang 
muncul pada negara tetangga di kawasan ASEAN-5, yaitu, Singapura, Thailand, Filipina dan Indonesia. Karakteristik umum dari pasar-pasar tersebut adalah pemberlakuan pajak pada perolehan modal, yang signifikan sendiri dalam literatur mengenai musim dalam pasar saham karena hipotesis penjualan kehilangan pajak telah menjadi penjelasan yang diterima secara luas mengenai efek musiman. Hasil sebelumnya menyebutkan bahwa efek musiman dalam pasar-pasar tersebut sangat mirip. Kecuali untuk Malaysia dimana efek musim secara tepat dihubungkan dengan efek Februari karena bulan ini melaporkan suatu pendapatan bulan rata-rata yang tinggi, dengan mengetahui efek musiman dalam rentang yang sedikit lebih luas (dengan memasukkan bulan dengan pendapatan tertinggi kedua) mengurangi perbedaan hampir nol. Secara khusus, sementara efek musiman terkait dengan efek Desember/Februari di Malaysia, saat ini dapat dihubungkan di dalam efek Desember/Januari dalam negaranegara ASEAN lainnya. Hasil-hasil dari model regresi pertama kami menegaskan bahwa efek musiman sangat signifikan dalam semua negara tersebut termasuk di Singapura. Dengan adanya hasil yang diperoleh dari pasar-pasar yang memberlakukan pajak pada perolehan modal menyediakan bukti yang sah yang menolak hipotesis penjualan hilang pajak.

Akhir pengujian bertujuan untuk menetapkan bukti tentang efek musim yang menular dalam pasar saham. Dengan mempergunakan uji sebab akibat (kausalitas) Granger pada data pendapatan secara keseluruhan, kami menemukan bukti bahwa beberapa pasar ekuitas membimbing yang lain. Model regresi yang dibentuk berdasarkan pada sebab akibat, arah-arah menegaskan bahwa terdapat efek-efek penularan dalam kinerja pasar saham umum. Penemuan ini lebih lanjut diteliti dengan melaksanakan uji sebab akibat Granger dengan hanya mempergunakan pendapatan bulanan musiman. Hasil-hasil tersebut menyebutkan bahwa Singapura yang dikalahkan oleh Filipina dan juga Thailand yang dikalahkan oleh Indonesia menetapkan kecenderungan dari gerakan pasar saham di Singapura dan juga di Thailand memiliki efek penularan pada musim di pasar ekuitas Malaysia. Untuk pasar modal Singapura, efek penularan kontemporan berasal dari Filipina, sementara bagi Indonesia, buktinya agak sedikit. Secara keseluruhan, analisis kami menyediakan bukti yang layak tentang efek penularan dari musim pasar saham di kawasan ASEAN. Dari sudut pandang investasi, efek penularan menyebutkan bahwa keputusan tidak boleh semata-mata berdasarkan pada kondisi yang ditegaskan dari satu pasar saja, tetapi pasar-pasar lain dalam kawasan sebagai satu kesatuan.

\section{DAFTAR PUSTAKA}

Abd-Rahim, R. (2003). Anomaly in the equity market: A re-Examination of January effect in Malaysia. Proceeding of the $5^{\text {th }}$ Asian Academy of Management Conference, 2, 374-383.

Abd-Rahim, R., Mat Sari, N., Mohd Saad,N. and Buniamin, S. (2005). Book-tomarket, firm size, trading activity, and February effects: Evidence from an emerging market. Proceeding of the $6^{\text {th }}$ Asian Academy of Management Conference, 2, 564-571.

Abd-Rahim, R, Harjito, D.A. and Mohd. Nor, A.A. (2006). Seasonility in the Asean Equity Markets: Is There Contagion Effect?. Jurnal Ekonomi and Studi Pembangunan, 7 (2): 217-235.

Badrinath, S.G. and Lewellen, W.G. (1991). Evidence on tax-motivated securities trading behavior. Journal of Finance, 46, 369 - 382. 
Cox, D.R. and Johnston, K. (1998). The January effect is not driven by tax loss selling. Journal of Investing (Winter), 105-111.

Dyl, E.A. (1977). Capital gain taxation and year end stock market behavior. Journal of Finance, 32, 165 - 175.

Dyl, E.A. and Maberly, E.D, (1992). Oddlot transactions around the turn of the year and January effect. Journal of Financial and Quantitative Analysis, 27, 591 - 604.

Eakins, S and Sewell, S. (1993). Tax-loss selling, institutional investors, and the January effect, A note. Journal of Financial Research, 16,377-384.

Fant, L.F. and Peterson, D.R. (1995). The effect of size, book-to-market equity, prior returns, and beta on stock returns: January versus the remainder of the year. Journal of Financial Research ,18, 129 - 142.

Givoly, D. and Ovadia, A. (1983). Year-end tax-induced sales and stock market seasonality. Journal of Finance, 38, $171-185$.

Gu, A.X. and Simon, J. (2004). Declining January effect: Experience in the United Kingdom. American Business Review, (June), 117-121.

Gultekin, M.N and Gultekin, B.N. (1983). Stock market seasonality, International evidence. Journal of Financial Economics, 12,469 - 481.

Haugen R.A. and Jorion, P. (1996). The January effect: Still there after all these years. Financial Analyst Journal, $27-31$.

Johnston, K. and Cox, D.R. (2002). Market index returns, macroeconomic variables, and tax-loss selling.
Journal of Financial Economics and Finance, 26 (3), 297 - 308.

Jones, C.P, Pearce, D.K. and Wilson, J.W. (1987). Can tax-loss selling explain the January effect? A note. The Journal of Finance, 453 - 461.

Kanas, A. (2005). Pure contagion effects in international banking: the case of BCCI's failure. Journal of Financial Economics, 8 (1),101-123.

Kato, K. and Schallheim, J.S. (1985). Seasonal and size anomalies in the Japanese stock market. Journal of Financial and Quantitative Analysis, 243 - 260.

Keim, D.B. (1983). Size-related anomalies and stock return seasonality: Further empirical evidence. Journal of Financial Economics, 12(1),13 32.

Masih, M.M. and Masih, R. (1999). Are Asian stock market fluctuations due mainly to intra-regional contagion effects? Evidence based on Asian emerging stock markets. Pacific Basin Finance Journa,l 7(3-4), 251 -282 .

Mehdian S. and Perry, M.J. (2002). Anomalies in US equity markets: A re-examination of the January effect. Applied Financial Economics, 141-145.

Narayan, P., Smyth, R. and Nandha, N. (2004). Interdependence and dynamic linkages between the emerging stock markets of South Asia. Accounting and Finance, 44, $419-439$

Pandey, I.M. (2002). Seasonality in the Malaysian stock market: 19922002. Journal of Financial Management and Analysis, 15(2), 37-44. 
Reinganum, M.R. (1983). The anomalous stock market behavior of small firms in January: Empirical tests for tax-loss selling effects. Journal of Financial Economics, 12 (1), 89 $-104$.

Rozeff, M.S. and Kinney, Jr. (1976). Capital market seasonality: The case of stock returns. Journal of Financial Economics, 3,379-402.

Silvapulle, P. (2004). Testing for seasonal behavior of monthly stock returns:
Evidence from international markets. Quarterly Journal of Business and Economics, 43 (1/2), 93-109.

Yong, O. (1991). Stock market seasonality: The Malaysian experience. In Rhee, S.G. and Chang, R.P. (editors) Pacific-Basin Capital Markets Research,2, 323-332, Amsterdam: North Holland Rotledge. 


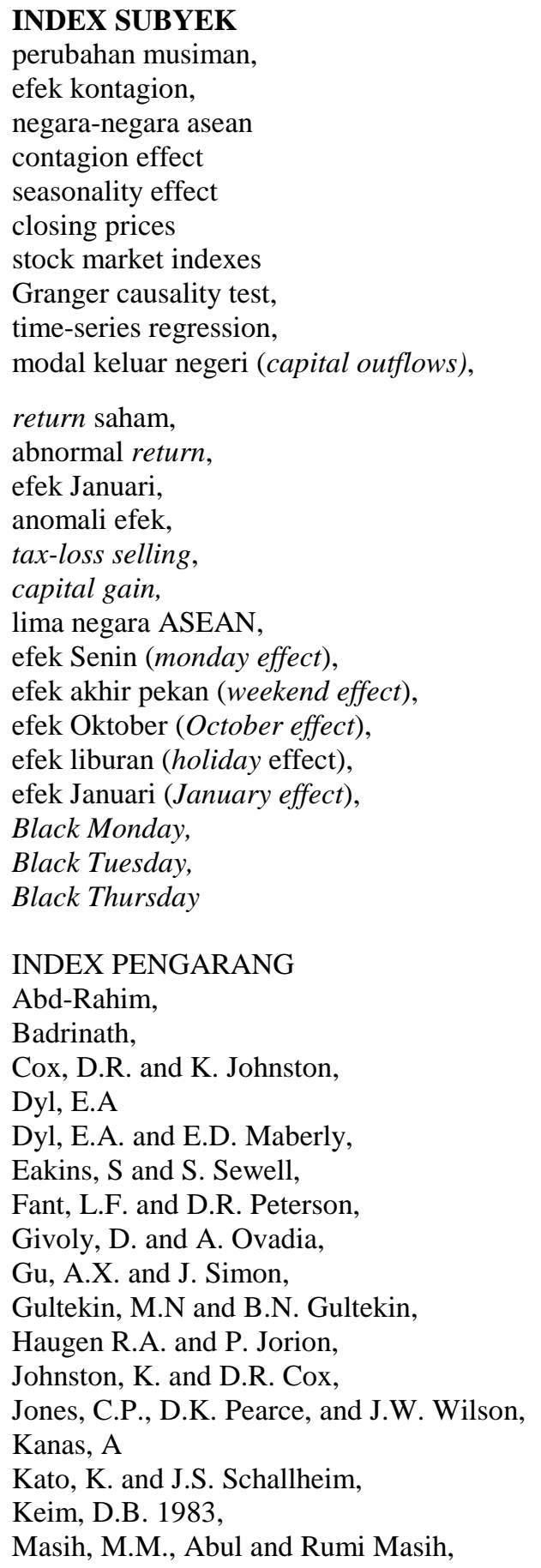


Mehdian S. and M.J. Perry,

Narayan, Paresh, Russel Smyth, and Mohan Nandha,

Pandey,

Reinganum,

Rozeff, M.S. and W.R. Kinney Jr, Silvapulle,

Yong, 